\title{
A Radioimmunoassay for Digoxin in Human Urine
}

\author{
By R. K. Marwaha and B. F. Johnson \\ Department of Clinical Pharmacology University of Massachusetts Medical School Worcester, \\ Massachusetts 01605
}

(Received June 6, 1983/February 16, 1984)

\begin{abstract}
Summary: We report a digoxin radioimmunoassay in human urine employing commercially available reagents. The calibration curve has a mean correlation coefficient of -0.994 and is linear up to $16.0 \mu \mathrm{g} / \mathrm{l}$. The average coefficients of variation between and within the runs are $3.6 \%$ and $3.5 \%$ respectively. The assay has a recovery of $101.4 \%$ and $98.9 \%$ at low and high levels of digoxin excretion respectively. Dihydrodigoxin at concentrations of 4,8 and $16 \mu \mathrm{g} / \mathrm{l}$ has relative cross reactivities of $12.0 \%, 7.7 \%$ and $4.8 \%$ respectively. The assay was applied to compare within-patient and between-patient variability during treatments with Lanoxin ${ }^{\circledR}$ and Lanoxicaps ${ }^{\circledR}$ at steady-state.
\end{abstract}

Precision, sensitivity, broad range linearity, convenience of commercially available reagents, insignificant cross reactivity of dihydrodigoxin with the digoxin antibody complex and urinary digoxin excretory data at different dilutions validate our assay for routine monitoring of urinary digoxin.

\section{Radioimmunassay für Digoxin im Harn des Menschen}

Zusammenfassung: Wir teilen einen Radioimmunassay für Digoxin im Harn des Menschen unter Verwendung käuflich erhältlicher Reagenzien mit. Die Standardkurve zeigt einen mittleren Korrelationskoeffizienten von $-0,994$ und ist bis zu $16 \mu \mathrm{g} / \mathrm{l}$ linear. Die mittleren Variationskoeffizienten in der Serie und von Tag zu Tag betragen 3,6\% bzw. 3,5\%. Das Verfahren hat eine Wiederfindung von 101,4\% bei niedrigen und $98,9 \%$ bei hohen Werten der Digoxinausscheidung. Dihydrodigoxin weist bei Konzentrationen von 4, 8 und $16 \mu \mathrm{g} / \mathrm{l}$ relative Kreuzreaktivitäten von $12,0,7,7$ bzw. 4,8\% auf.

Die Bestimmung wurde für den Vergleich der Variabilität am gleichen Patienten und zwischen den Patienten während der Behandlung mit Lanoxin ${ }^{\circledR}$ und Lanoxicaps ${ }^{\circledR}$ im Gleichgewichtszustand angewandt.

Präzision, Ëmpfindlichkeit, weiter Linearitätsbereich, die Annehmlichkeit käuflich erhältlicher Reagenzien, unbedeutende Kreuzreaktivität von Dihydrodigoxin mit dem Digoxin-Antikörper-Komplex sowie die Daten für die Ausscheidung von Digoxin im Harn bei unterschiedlichen Verdünnungen zeigen den Wert der Methode für die rouitinemäßige Uberprüfung von Digoxin im Harn.

\section{Introduction}

Research work involving cardioglycosides has been limited to some extent by scarcity of information about radioimmunoassays for digoxin in human urine $(1-5)$. The present work was undertaken to modify a commercially available radioimmunoassay kit to develop a simple and convenient method that was usable for urine samples. In addition we checked the relative cross reactivity of dihydrodigoxin with the digoxin antibody complex used in the assay. 


\section{Methods and Materials}

Reagents

Assay buffer

Monosodium phosphate monohydrate $(1.84 \mathrm{~g})$, disodium phosphatc $(3.78 \mathrm{~g})$ and sodium azide $(1.0 \mathrm{~g})$ were dissolved in $600 \mathrm{ml}$ of deionized water. $5.0 \mathrm{~g}$ of bovine serum albumin (RIA-grade, Fraction V, Sigma Chemical Company, P.O. Box 14508, St. Louis, MO 63178) was added with constant stirring. The solution was adjusted to $\mathrm{pH} 7.4$ at room temperature with $10 \mathrm{~mol} / \mathrm{l} \mathrm{NaOH}$ and then diluted with deionized water to 1.01 in a volumetric flask.

\section{Digoxin stock solution}

Crystalline digoxin (10 mg, No. C037, Burroughs Wellcome Company, Research Triangle Park, NC 27709) was weighed out to the hundreth of a milligram and dissolved in $250 \mathrm{ml}$ of ethanol/ water $(80+20$ by volume). The first ten fold dilution in ethanol/ water $(20+80$ by volume) was followed with another ten fold dilution in assay buffer to produce a digoxin stock solution of 0.4 $\mathrm{mg} /$.

\section{Urine stock, standards and controls}

Digoxin stock solution $(10 \mathrm{ml})$ was made up to $50 \mathrm{ml}$ with digoxin-free normal human urine to produce a urine stock of $80 \mu \mathrm{g} / \mathrm{l}$ concentration. The urine standards $0.64,0.96,2.0,4.0,8.0$ and $16.0 \mu \mathrm{g} /$ were prepared by appropriate dilution of urine stock with assay buffer. A zero concentration of standard stock urine was made by five fold dilution of digoxin-free normal human urine with assay buffer.

The controls in low $(16 \mu \mathrm{g} / \mathrm{l})$, mid $(40 \mu \mathrm{g} / \mathrm{l})$ and high $(80 \mu \mathrm{g} / \mathrm{l})$ ranges were made by spiking digoxin-free normal human urine with digoxin stock solution. For recovery studies, two urine pools with $24 \mu \mathrm{g} / \mathrm{h}$ and $48 \mu \mathrm{g} / \mathrm{l}$ concentration were prepared from digoxin stock solution in the same way as the urine controls.

Dihydrodigoxin (Kontroll-Nr. 202385, Boehringer Mannheim Biochemicals, Indianapolis, IN 46250) stock solution of $0.4 \mathrm{mg} / \mathrm{l}$ was also prepared in the same way as the digoxin stock solution. For cross reactivity studies, the digoxin-free normal human urine was spiked with dihydrodigoxin stock solution to produce concentrations of 4,8 and $16 \mu \mathrm{g} /$.

\section{I-labelled digoxin and antiserum complex}

Both ${ }^{125}$ I-labelled digoxin and antiserum complex (part of the regular RIA-NEN Digoxin (I-125) radioimmunoassay kit, Cat. No. NEA 082, New England Nuclear, North Billerica, MA 01862) were used as such. The digoxin antibody variations were minimized by using a single lot of antiserum complex (Lot No. PC-033) and blank antiserum (Lot No. PC-231).

\section{Assay procedure}

The RIA was done by pipetting duplicate $0.1 \mathrm{mI}$ aliquots of each standard into $12 \times 75 \mathrm{~mm}$ borosilicate glass tubes containing $0.1 \mathrm{ml}$ digoxin-free normal human serum. This was followed with the addition of $0.5 \mathrm{ml}$ of ${ }^{125} \mathrm{I}$-labelled digoxin into each tube, and the mixture was vortexed. As soon as tracer ( ${ }^{125}$ I-labelled digoxin) was added, each tube was mixed with $0.5 \mathrm{ml}$ of antiserum complex and incubated for $30 \mathrm{~min}$ at room temperature. Subsequently, the tubes were centrifuged at $1674 \mathrm{~g}$ for $10 \mathrm{~min}$, decanted and counted for radioactivity in a gamma scintillation counter (Model Searle 1185, Tracor Analytical Inc., 1842 Brummel Drive, Elk Grove Village, IL 60007).

The duplicate set of nonspecific binding tubes was prepared by pipetting $0.1 \mathrm{ml}$ of urine zero standard into $12 \times 75 \mathrm{~mm}$ borosilicate glass tubes containing $0.1 \mathrm{ml}$ of digoxin-free normal human serum, and they were processed in the same way as standards except antiserum addition was replaced by the same volume of blank antiserum. The urine controls and recovery samples were diluted before analysis so that their concentration fell in the middle portion of the calibration curve. The concentration in the samples was calculated using $\log -\log$ transformation and then multiplying with the dilution factor of the sample.

Dihydrodigoxin spiked samples were run in the same way as standards and controls. The apparent digoxin concentration for dihydrodigoxin was calculated using the same log-log transformation and digoxin calibration curve.

\section{Results and Discussion}

Table 1 summarizes the assay data for seventeen urinary digoxin assays. The calibration curve has a mean correlation coefficient of $-0.994 \pm 0.0025$ using $\log -\log$ transformation. The curve is linear up to $16.0 \mu \mathrm{g} / \mathrm{l}$ when plotted on a logit-log graph (fig. 1). Data in table 1 and figure 1 suggest good reproducibility, resolution and linearity over a broad range.

The intra-assay variation determined using ten replicates at low $(16 \mu \mathrm{g} / \mathrm{l})$, mid $(40 \mu \mathrm{g} / \mathrm{l})$ and high $(80$ $\mu \mathrm{g} / \mathrm{l})$ concentrations is shown in table 2 . Day to day

Tab. 1. Relative binding data for seventeen digoxin calibration curves.

\begin{tabular}{|c|c|c|}
\hline $\begin{array}{l}\text { Sample } \\
\text { No. }\end{array}$ & $\begin{array}{l}\text { Concentration } \\
(\mu g / l)\end{array}$ & $\begin{array}{l}\mathrm{B} / \mathrm{B}_{0} \\
(\text { Mean } \pm \mathrm{SD})\end{array}$ \\
\hline 1 & 0.64 & $0.808 \pm 0.0099$ \\
\hline 2 & $\therefore \quad \cdots \cdots \cdot$ & $0.701 \pm 0.0154$ \\
\hline 3 & 2.0 & $0.490 \pm 0.0239$ \\
\hline 4 & 4.0 & $0.294 \pm 0.0158$ \\
\hline 5 & 8.0 & $0.160 \pm 0.0072$ \\
\hline 6 & 16.0 & $0.088 \pm 0.0061$ \\
\hline
\end{tabular}

Mean correlation coefficient $=-0.994 \pm 0.0025$ (log-log transformation).

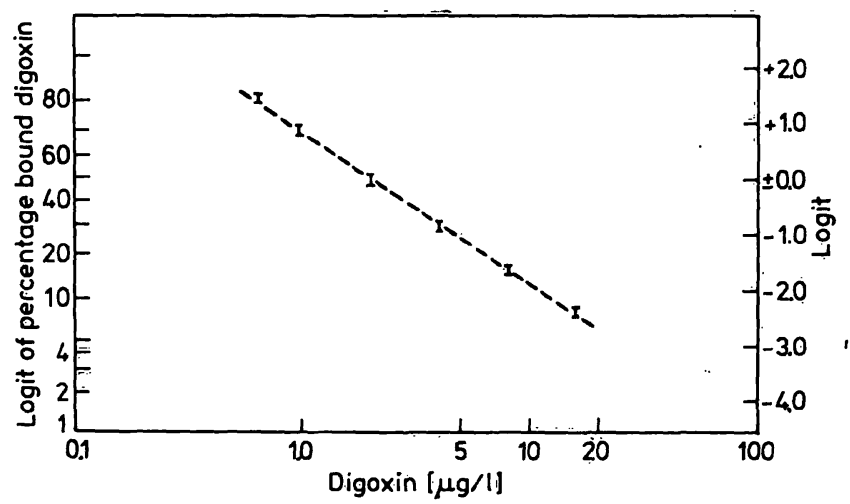

Fig. 1. Composite calibration curve of seventeen urinary digoxin assays. Log of digoxin concentration (abscissa) is plotted against logit of percentage bound $\left(B / B_{0}\right)$. Bars indicate one standard deviation about the mean value calculated for each duplicate assay. 
Tab. 2. Assessment of reproducibility.

\begin{tabular}{llllll}
\hline $\begin{array}{l}\text { Di- } \\
\text { goxin } \\
\text { concen- } \\
\text { tration } \\
(\mu \mathrm{g} / \mathrm{l})\end{array}$ & $\mathrm{n}$ Mean \pm S.D. & $\mathrm{CV}$ & & \multicolumn{2}{l}{ Interassay variation } \\
Mean \pm S.D. & $\mathrm{CV}$ \\
\hline 16 & $17.17 \pm 0.35$ & 2.06 & 13 & $17.18 \pm 1.08$ & 2.64 \\
40 & $39.11 \pm 1.92$ & 4.92 & 15 & $39.00 \pm 1.79$ & 4.55 \\
80 & $82.80 \pm 3.02$ & 3.64 & 15 & $82.81 \pm 3.06$ & 3.69 \\
\hline
\end{tabular}

$* \mathrm{n}=$ Number of assays run in duplicate

Tab. 3. Analytical recovery of digoxin.

\begin{tabular}{lcl}
\hline & I & II \\
\hline Digoxin added $(\mu \mathrm{g} / \mathrm{l})$ & 24 & 48 \\
Digoxin recovered $(\mu \mathrm{g} / \mathrm{l})$ & $24.33 \pm 0.56$ & $47.47 \pm 1.6$ \\
Recovery $(\%)$ & 101.4 & 98.9 \\
$\mathrm{n}^{*}$ & 13 & 14 \\
\hline
\end{tabular}

* $\mathrm{n}=$ Number of assays run in duplicate

variability at low, mid and high control levels is insignificant (tab. 2). The assay accuracy determined by analytical recovery studies is $101.4 \%$ at a low level of digoxin excretion and $98.9 \%$ at a high level of digoxin excretion (tab. 3). The relative cross reactivities of dihydrodigoxin at concentrations of 4,8 and $16 \mu \mathrm{g} / 1$ are $12.0 \%, 7.7 \%$, and $4.8 \%$ respectively (tab. 4).

The present assay is linear up to $16.0 \mu \mathrm{g} / \mathrm{l}$ in contrast to linearity up to $6.3 \mu \mathrm{g} / \mathrm{l}$ of a recently reported radioimmunoassay for urinary digoxin measurement (4). As urinary digoxin levels are always much higher and more variable than plasma digoxin levels, it is usually necessary to analyze multiple dilutions of each sample. The broad range linearity of our calibration curve obviates this need.
Dihydrodigoxin is the major cardio-inactive metabolite of digoxin found in measurable quantity in human plasma (6), and urine (7). Its cross reactivity with commercially available digoxin RIA kits can vary as much as $30 \%(8-9)$. This may be due to the difference in antibody titer, method of attaching radiolabel to digoxin or digoxin derivative, or separation techniques employed in the kit for bound and free antigen (8-10). A high degree of dihydrodigoxin) cross reactivity with digoxin antibody will not only give false plasma digoxin levels, but will also affect bioavailability data based on urinary measurements (11). The relative cross reactivity for dihydrodigoxin of up to $12.0 \%$ in the present assay will produce insignificant change in urinary digoxin measurements.

The present assay was used to compare within-patient and between-patient variability for cumulative digoxin excretion during treatments with Lanoxin ${ }^{\circledR}$ (digoxin in tablet) and Lanoxicaps ${ }^{\circledR}$ (digoxin solution in capsule) in patients in whom steady state serum concentrations were in the therapeutic range $(0.8-2.0 \mu \mathrm{g} / 1)$. These treatments were compared in a multiple dose, cross-over design study in 29 adult patients who required digoxin.

Every patient was studied for two treatment periods each lasting four weeks. The patients consumed their daily dose of Lanoxin ${ }^{\circledR}$ tablets or Lanoxicaps ${ }^{\circledR}$ as a single dose at 9:30 a.m. (after breakfast). Four urine samples, one each during the 3rd, 4th, 7th and 8th week of the study period in each patient, were collected and analyzed for 24 hour cumulative digoxin excretion. Each urine collection started when the last maintenance dose was administered and terminated 24 hours later. Table 5 documents 24 hour cumulative digoxin excretion during the $3 \mathrm{rd}, 4 \mathrm{th}, 7 \mathrm{th}$ and 8 th week of the study period in two representative patients.

Thus, the precision, broad-range linearity, availability of commercially available reagents, insignificant

Tab. 4. Relative cross reactivity of dihydrodigoxin with digoxin antibody complex.

\begin{tabular}{|c|c|c|c|c|}
\hline No. & $\begin{array}{l}\text { Dihydrodigoxin } \\
\text { concentration } \\
(\mu \mathrm{g} / \mathrm{l})\end{array}$ & $\mathrm{n}^{*}$ & $\begin{array}{l}\text { Mean cross reactivity as } \\
\text { apparent digoxin using } \\
\text { log-log transformation } \\
(\mu \mathrm{g} / \mathrm{l})^{\mathrm{a}}\end{array}$ & $\begin{array}{l}\% \text { Relative cross reactivity } \\
=\frac{\text { Apparent concentration of digoxin }}{\text { amount of dihydrodigoxin }}\end{array}$ \\
\hline $\begin{array}{l}1 \\
2 \\
3\end{array}$ & $\begin{array}{r}4 \\
8 \\
16\end{array}$ & $\begin{array}{l}6 \\
6 \\
6\end{array}$ & $\begin{array}{l}0.481 \pm 0.056 \\
0.619 \pm 0.064 \\
0.767 \pm 0.082\end{array}$ & $\begin{array}{r}12.0 \\
7.7 \\
4.8\end{array}$ \\
\hline
\end{tabular}

\footnotetext{
* $n=$ Number of assays performed in duplicate

a Due to small differences in molecular weight ( 2 mass units) the concentrations of both digoxin and dihydrodigoxin are expressed in $\mu \mathrm{g} /$.
} 
Tab. 5. Cumulative 24-hour digoxin excretion in urine samples of two patients.

\begin{tabular}{|c|c|c|c|c|c|c|c|}
\hline Subject & $\begin{array}{l}\text { Maintenance } \\
\text { dose } \\
\text { (mg/day) }\end{array}$ & Digoxin brand & $\begin{array}{l}\text { Treat- } \\
\text { ment } \\
\text { week }\end{array}$ & $\begin{array}{l}\begin{array}{l}\text { Urine } \\
\text { volume }\end{array} \\
\text { (ml) }\end{array}$ & $\begin{array}{l}\text { Dilution } \\
\text { factor }\end{array}$ & $\begin{array}{l}\text { Urine digoxin* } \\
(\mu g / l) \\
\text { Mean } \pm \text { S.D. }\end{array}$ & $\begin{array}{l}\text { Cumulative } \\
\text { 24-hour } \\
\text { urinary digoxin } \\
(\mu \mathrm{g})\end{array}$ \\
\hline \multirow[t]{2}{*}{ R.C.H. } & $\begin{array}{l}0.3125 \\
0.3125\end{array}$ & $\begin{array}{l}\text { Lanoxin }^{\circledR} \\
\text { Lanoxin }^{\circledR}\end{array}$ & $\begin{array}{l}3 \\
4\end{array}$ & $\begin{array}{r}1880 \\
790\end{array}$ & $\begin{array}{l}33.33 \\
33.33\end{array}$ & $\begin{array}{l}2.90 \pm 0.064 \\
4.21 \pm 0.076\end{array}$ & $\begin{array}{l}182.0 \\
110.7\end{array}$ \\
\hline & $\begin{array}{l}0.250 \\
0.250\end{array}$ & $\begin{array}{l}\text { Lanoxicap }{ }^{\circledR} \\
\text { Lanoxicap }{ }^{\circledR}\end{array}$ & $\begin{array}{l}7 \\
8\end{array}$ & $\begin{array}{l}1920 \\
2020\end{array}$ & $\begin{array}{l}33.33 \\
10 \\
25 \\
10\end{array}$ & $\begin{array}{l}1.08 \pm 0.051 \\
3.60 \pm 0.147 \\
0.61 \pm 0.029 \\
1.43 \pm 0.083\end{array}$ & $\begin{array}{l}69.4 \\
69.1 \\
30.7 \\
28.8\end{array}$ \\
\hline \multirow[t]{2}{*}{ M.R. } & $\begin{array}{l}0.250 \\
0.250\end{array}$ & $\begin{array}{l}\text { Lanoxin }{ }^{\circledR} \\
\text { Lanoxin }{ }^{\circledR}\end{array}$ & 3 & $\begin{array}{r}650 \\
2770\end{array}$ & $\begin{array}{l}10 \\
25 \\
10\end{array}$ & $\begin{array}{l}9.07 \pm 0.101 \\
3.79 \pm 0.047 \\
6.74 \pm 0.087\end{array}$ & $\begin{array}{r}59.0 \\
61.7 \\
186.6\end{array}$ \\
\hline & $\begin{array}{l}0.200 \\
0.200\end{array}$ & $\begin{array}{l}\text { Lanoxicap }{ }^{\circledast} \\
\text { Lanoxicap }\end{array}$ & $\begin{array}{l}7 \\
8\end{array}$ & $\begin{array}{r}1140 \\
830\end{array}$ & $\begin{array}{l}10 \\
10 \\
25\end{array}$ & $\begin{array}{l}6.80 \pm 0.210 \\
9.16 \pm 0.057 \\
3.72 \pm 0.135\end{array}$ & $\begin{array}{l}77.5 \\
75.8 \\
77.0\end{array}$ \\
\hline
\end{tabular}

* Each assay was run in quadruplicate.

dihydrodigoxin cross-reactivity with digoxin antibody complex, and urinary digoxin excretory data at different dilutions under normal clinical conditions provide an excellent basis for the use of our assay for routine urinary digoxin measurements.

\section{References}

1. Brock, A. (1974) Acta Pharmacol. Toxicol. 34, 198-204.

2. Greenwood, H., Snedden, W., Hayward, R. P. \& Landon, J. (1975) Clin. Chim. Acta 62, 213-224.

3. Nore, A. K., Storstein, L., Larsen, A. \& Amlie, J. P. (1980) Clin. Chem. 26, 321-323.

4. Christenson, R. H., Hammond, J. E., Hull, J. H. \& Bustrack, J. A. (1982) Clin. Chim. Acta 120, 13-19.

5. Wagner, J. G., Hallmark, M. R., Sakmar, E. \& Ayres, J. W. (1977) Steroids 29, 787-807.

6. Clark, D. R. \& Kalman, S. M. (1974) Drug Metab. Dispos. 2, $148-150$.
7. Lindenbaum, J., Tse-Eng, D., Butler, V. P. Jr. \& Rund, D. G. (1981) Am. J. Med. 71, 67-74.

8. Oge, E. K. \& Polonus, P. A. (1978) Clin. Chem. 24, 1086.

9. Kramer, W. G., Bathala, M. S.\& Reuming, R. H. (1976) Res. Commun. Chem. Pathol. Pharmacol. 14, 83-88.

10. Kramer, W. G., Kinnear, N. L. \& Morgan, H. K. (1978) Clin. Chem. 24, 155-157.

11. Malini, P. L., Marata, A. M., Strocchi, E. \& Ambrosioni, E. (1982) Clin. Chem. 28, 2445-2446.

Raj K. Marwaha

Division of Clinical Pharmacology

Univ. of Massachusetts Medical Center

55 Lake Avenue North

Worcester, Mass 01605

USA 